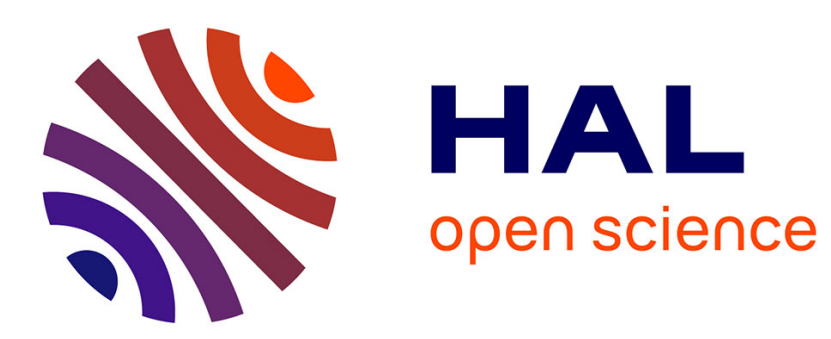

\title{
Detection of S-acylated CD95 by acyl-biotin exchange
}

Aurélie Rossin, Anne-Odile Hueber

\section{To cite this version:}

Aurélie Rossin, Anne-Odile Hueber. Detection of S-acylated CD95 by acyl-biotin exchange. CD95 Methods and Protocols, 2017, 10.1007/978-1-4939-6780-3_17 . hal-03541907

\section{HAL Id: hal-03541907 https://hal.science/hal-03541907}

Submitted on 25 Jan 2022

HAL is a multi-disciplinary open access archive for the deposit and dissemination of scientific research documents, whether they are published or not. The documents may come from teaching and research institutions in France or abroad, or from public or private research centers.
L'archive ouverte pluridisciplinaire HAL, est destinée au dépôt et à la diffusion de documents scientifiques de niveau recherche, publiés ou non, émanant des établissements d'enseignement et de recherche français ou étrangers, des laboratoires publics ou privés. 


\title{
Detection of S-acylated CD95 by acyl-biotin exchange
}

\author{
Aurelie Rossin ${ }^{1}$, and Anne-Odile Hueber ${ }^{1, *}$ \\ ${ }^{1}$ Université de Nice, Institut de Biologie Valrose, CNRS UMR 7277, INSERM UMR 1091, \\ Nice, France. \\ * Corresponding author: A-O. Hueber
}

Université de Nice, Institut de Biologie Valrose, CNRS UMR 7277, INSERM UMR 1091, Parc Valrose, Bâtiment des Sciences Naturelles, Nice, France.

hueber@unice.fr

\section{Running title: CD95 S-acylation detection}

\section{Summary}

S-acylation is the covalent addition of a fatty acid, most generally palmitate onto cysteine residues of proteins through a labile thioester linkage. The death receptor CD95 is Spalmitoylated and this post-translational modification plays a crucial role on CD95 organization in cellular membrane and thus on CD95-mediated signaling. Here, we describe the non-radioactive detection of CD95 S-acylation by acyl-biotin exchange chemistry in which a biotin is substituted for the CD95-linked fatty acid. This sensitive technique, which depends on the ability of hydroxylamine to specifically cleave the thioester linkage between fatty acids and proteins, relies on 3 chemical steps: (i) blockage of free thiols of non-modified 
cysteine residues, (ii) hydroxylamine-mediated cleavage of thioester-linked fatty-acids to restore free thiols and (iii) biotinylation of free thiols with a thiol reactive biotinylation agent. Resulting biotinylated proteins can be easily purified by an avidin capture and analysed by SDS-PAGE and immunoblotting.

Key words: S-acylation, S-palmitoylation, hydroxylamine, acyl-biotin exchange

\section{Introduction}

Protein functions are regulated by diverse chemical modifications including lipid modifications, such as myristoylation, prenylation or S-acylation. S-acylation is the posttranslational addition of a fatty acid onto the cysteine residues of proteins via a labile thioester linkage (1). Palmitic acid (16 carbons) being the predominant fatty acid linked to Sacylated proteins, this modification is generally referred as S-palmitoylation, even though other fatty acids such as oleate and stearate can be incorporated in S-acylated proteins (2). S-acylation can affect the affinity of proteins for membranes thus playing a role in membrane domains targeting, cellular trafficking and protein stability (1). In contrast to other lipidations, S-acylation is reversible and dynamically regulated by different enzymes, allowing cycles of acylation/deacylation. Indeed, the 23 members of the zDHHC protein family (characterized by the specific DHHC domain) have been described to have an acyltransferase activity while three thioesterases (PPT1, PPT2 and APT1) have been identified to date $(2,3)$. A wide variety of proteins are modified by S-acylation including transmembrane signaling receptors, ion channels or chaperones and increasing numbers of 
DHHC/acylated substrate pairs have been identified (4). The recent development of new techniques, such as acyl-biotin exchange $(A B E)$ to detect this modification has overcome the limitations of metabolic labelling and allowed to expand the list of known S-acylated proteins (5-7).

The importance of protein S-palmitoylation in tumor necrosis factor receptor (TNFR) superfamily signaling was reported by several scientific teams in the recent years (8-13) and our work demonstrated that this modification is necessary for an optimal cell death triggering. In particular, we focused on the CD95/CD95 ligand (CD95L) system since both proteins are constitutively S-palmitoylated $(8,10)$. Upon its activation by CD95L binding, the death receptor CD95 is able to initiate various signaling cascades leading either to cell death or to non-cell death functions (14). At the molecular level, CD95 S-palmitoylation occurs on the intracellular cysteine 199 , close to the transmembrane domain, and is catalyzed by zDHHC7 (15). At a functional level, S-palmitoylation regulates CD95 expression and organization at the plasma membrane by allowing (i) CD95 targeting in specific membrane nanodomains enriched in cholesterol and sphingolipids (often referred as lipid rafts)(8), (ii) formation of CD95 aggregates (9) and (iii) maintenance of a proper CD95 surface expression by preventing its degradation by the lysosomes(15).

So far, S-acylation has been detected using few techniques including metabolic labeling of cultured cells with radiolabeled palmitate $\left({ }^{3} \mathrm{H}\right.$-palmitate) and acyl-biotin exchange (ABE). Some years ago, metabolic labeling was the most commonly used assay. Briefly, radiolabeled palmitate is incorporated in S-palmitoylated proteins, which is followed by cell lysis, immunoprecipitation of the protein of interest and resolution on SDS-PAGE for autoradiography analysis. More recently, Drisdel and Green developed a protocol called ABE 
that we adapted to detect CD95 S-acylation and which relies on 3 principal steps(5)(Fig.1): (i) blockage of free thiols by the methylthiolating agent methylmethanethiosulfonate (MMTS), (ii) specific cleavage of thioester-linked fatty acid moieties by hydroxylamine to restore free thiols and (iii) biotinylation of the released free thiols by the thiol-reactive biotinylation agent biotin-HPDP (N-[6-(biotinamido)hexyl]-3'-(2'-pyridyldithio)propionamide). In Sacylated proteins the fatty acids are substituted by a biotin. They can therefore be isolated by an avidin-affinity resin from the total protein lysate, resolved on a SDS-PAGE followed by immunoblotting. One should nevertheless keep in mind that $A B E$ and metabolic labelling do not detect completely overlapping fatty acid modifications (see Note 1).

Both techniques present advantages and limitations. However, we decided to use the $A B E$ protocol and adapted it to routinely analyze CD95 S-acylation for several reasons: (i) the metabolic labelling strategy presented some sensitivity limitations due to the the facts that Fas expression level is quite low in the majority of the cells and that the anti-Fas immunoprecipitation step restricts the analysis to some Fas subpopulations molecules. As a consequence, several weeks or months exposure were needed to get a detectable signal on autoradiography. Comparatively, $\mathrm{ABE}$ is a very sensitive technique which allows the detection of endogenous S-acylated Fas by a simple western blot, the limit being here the sensitivity of the antibody used for immunoblotting detection; (ii) contrary to metabolic labelling, $A B E$ is a non-radioactive technique which can be easily handled in a laboratory with classical security rules; (iii) while metabolic labeling is restricted to S-acylation detection in living cells, protein S-acylation status can be also assessed on tissue samples by the ABE technique. 
However, important controls must be included in the $A B E$ experiment and particular care has to be taken in order to avoid false positive hits (this will be discussed in the following protocol).

\section{Materials}

\subsection{Cell lysate preparation}

1. PBS 1X: $137 \mathrm{mM} \mathrm{NaCl}, 2.7 \mathrm{mM} \mathrm{KCl}, 10 \mathrm{mM} \mathrm{Na}_{2} \mathrm{HPO}_{4}, 1.8 \mathrm{mM} \mathrm{KH}_{2} \mathrm{PO}_{4}$.

2.Protease inhibitor cocktail: for $10 \mathrm{ml}$, combine the following components: $2 \mathrm{ml}$ of $5 \mathrm{mg} / \mathrm{ml}$ Leupeptin, dissolved in water; $2 \mathrm{ml}$ of $12.5 \mathrm{U} / \mathrm{ml}$ ү2-macroglobulin, dissolved in water; $1 \mathrm{ml}$ of $10 \mathrm{mg} / \mathrm{ml}$ pepstatin $\mathrm{A}$, dissolved in DMSO; $1 \mathrm{ml}$ of $10 \mathrm{mg} / \mathrm{ml}$ chymostatin, dissolved in DMSO; and $4 \mathrm{ml}$ of water. Mix well. Make small single-use aliquots of the stock solution and store at $-20^{\circ} \mathrm{C}$.

3. HES lysis buffer: $250 \mathrm{mM}$ Hepes $\mathrm{pH} 7.4,1 \mathrm{mM}$ ethylenediaminetetraacetic acid (EDTA), 2\% sodium dodecyl sulfate (SDS), $0.1 \%$ protease inhibitor cocktail.

4. Sonicator for small sample size (eg Vibra Cell 75022).

5. Refrigerated benches centrifuges for $50 \mathrm{ml}$ and Eppendorf tubes.

6. Reagents for detergent compatible protein quantification (eg $D C^{\mathrm{TM}}$ protein assay, Biorad).

\subsection{Acyl-biotin exchange}

1. Blocking buffer (BB): $250 \mathrm{mM}$ Hepes $\mathrm{pH}$ 7.4, $1 \mathrm{mM}$ EDTA, 2.5\% SDS, $20 \mathrm{mM}$ methylmethanethiosulfonate (MMTS) (see Note 2). 
2. Agitating water bath set to $50^{\circ} \mathrm{C}$.

3. $100 \%$ ice-cold acetone.

4. 4HES: 50 mM Hepes pH 7.4, 1 mM EDTA, 4\% SDS, 0.1\% protease inhibitor cocktail.

5. HA buffer: $0.7 \mathrm{M}$ Hydroxylamine (see Note 3), $1 \mathrm{mM}$ Biotin-HPDP (see Note 4), $0.2 \%$ triton X-100, 0.1\% protease inhibitor cocktail.

6. -HA buffer: $50 \mathrm{mM}$ Hepes, $1 \mathrm{mM}$ biotin-HPDP, $0.2 \%$ triton $\mathrm{X}-100,0.1 \%$ protease inhibitor cocktail.

\subsection{Avidin capture}

1. Dilution Buffer (DB): 20 mM Hepes pH 7.4, $100 \mathrm{mM} \mathrm{NaCl} 1 \mathrm{mM}$ EDTA, 0.5\% Triton X-100, $0.1 \%$ protease inhibitor cocktail.

2. Washing Buffer (WB): 20 mM Hepes pH 7.4, 600 mM NaCl, 1 mM EDTA, 0.5\% Triton X-100, $0.1 \%$ protease inhibitor cocktail.

3. Neutravidin-agarose beads (see Note 5).

4. Laemmli buffer $4 \mathrm{X}$ : $240 \mathrm{mM}$ Tris- $\mathrm{HCl}$ pH $6.8,8 \%$ SDS, $40 \%$ glycerol, $0.04 \%$ bromophenol blue.

5. $\beta$-mercaptoethanol.

\subsection{SDS-PAGE and western blot.}

1. $8 \%$ resolving gel buffer (for $12 \mathrm{ml}$ ): $\mathrm{mix} 3.2 \mathrm{ml}$ of acrylamide/bis solution (29:1), $120 \mu \mathrm{l}$ of $10 \% \mathrm{SDS}, 5.6 \mathrm{ml} \mathrm{H} 2 \mathrm{O}, 3 \mathrm{ml}$ of Tris $-\mathrm{HCl} 1.5 \mathrm{M} \mathrm{pH} \mathrm{8.8,6 \mu l}$ of tetramethylethylenediamine (TEMED) and $60 \mu \mathrm{l}$ of $10 \%$ ammonium persulfate (APS). 
2. Stacking gel buffer (for $5 \mathrm{ml}$ ): mix $0.66 \mathrm{ml}$ of acrylamide/bis solution (29:1), $50 \mu \mathrm{l}$ of $10 \%$ SDS, $3 \mathrm{ml} \mathrm{dH} 2 \mathrm{O}, 1.26 \mathrm{ml}$ of Tris- $\mathrm{HCl} 0.5 \mathrm{M} \mathrm{pH} 6.8,5 \mu \mathrm{l}$ of TEMED and $25 \mu \mathrm{l}$ of $10 \%$ APS.

3. Running buffer: $2.5 \mathrm{mM}$ Tris pH 8.3, $19.2 \mathrm{mM}$ glycine, $0.01 \%$ SDS.

4. PVDF membrane.

5. Transfer buffer: $2.5 \mathrm{mM}$ Tris pH 8.3, $19.2 \mathrm{mM}$ Glycine, 20\% EtOH.

6. Tris-buffered saline tween (TBS-T) 10X: 200 mM Tris-Hcl pH 7.4, 275 mM NaCl, 1\% Tween 20.

7. Blocking solution: $4 \%$ milk in TBS-T $1 X$.

8. First antibody dilution: $1 / 1000$ in blocking solution. We used several antibodies to detect CD95 S-acylation: the mouse monoclonal anti-CD95 antibody B10 (Santa Cruz), the polyclonal anti-CD95 antibody C20 (Santa Cruz) and 2 rabbit monoclonal antibodies EPR520 and EPR5700 (Abcam). For the internal controls we used a rabbit polyclonal anti-fyn antibody (Santa Cruz) and a mouse monoclonal anti-GAPDH antibody (Calbiochem).

9. Secondary antibody dilution: anti-mouse or anti-rabbit secondary antibodies linked to horseradish peroxidase (HRP) are diluted to 1/10000 in blocking solution.

10. $\mathrm{ECL}$ reagent for chimioluminescence detection.

\section{Method}

\subsection{Cell lysate preparation}

We could detect endogenous CD95 S-acylation in both adherent and suspension cells (Fig.2a and b) (see Note 6). For suspension cells, centrifuge the appropriate number of cells (see 
Note 7) at $300 \mathrm{~g}$ for $5 \mathrm{~min}$ at $4^{\circ} \mathrm{C}$. Resuspend the cell pellet in cold PBS $1 \mathrm{X}$ and transfer the cells in an Eppendorf tube. Centrifuge at $300 \mathrm{~g}$ for $5 \mathrm{~min}$ at $4^{\circ} \mathrm{C}$ (see Note 8). Remove the supernatant and lyse the cell pellet with $1 \mathrm{ml}$ of HES lysis buffer (see Note 9). In the case of adherent cells (see Note 7), put the plates on ice, remove the cell media, wash the cells with cold PBS $1 X$ (see Note 8 ) and add $1 \mathrm{ml}$ of lysis buffer on the plate. After scrapping the cells, recover the lysis solution and transfer in an Eppendorf tube. The lysis solution is viscous due to the presence of DNA. Sonicate the samples 2 times $10 \mathrm{sec}(4 \mathrm{~W})$ on ice to obtain a clear lysate.

Quantify your lysates for protein content using a detergent-compatible protein assay. Ideally, $3 \mathrm{mg}$ of proteins per point are required.

\section{2. $A B E$}

All the following steps have to be carried out under a chemical hood.

3.2.1. Free thiol blockage: put $3 \mathrm{mg}$ of proteins in a $50 \mathrm{ml}$ conical tube and adjust volume to $2 \mathrm{ml}$ with HES lysis buffer. Add $8 \mathrm{ml}$ of blocking buffer (see Note 10). Incubate the samples in a waterbath at $50^{\circ} \mathrm{C}$ for 20 minutes under permanent agitation and frequent manual mixing.

3.2.2. Protein precipitation and MMTS removal (see Note 11): add $20 \mathrm{ml}$ of ice-cold acetone, mix by inverting the tubes and incubate for $15 \mathrm{~min}$ at $-20^{\circ} \mathrm{C}$. Centrifuge at $2500 \mathrm{~g}$ for $5 \mathrm{~min}$ at $4^{\circ} \mathrm{C}$. You obtain a visible white protein pellet. Discard the supernatant and wash the pellet with $5 \mathrm{ml}$ ice-cold acetone. Centrifuge at $2500 \mathrm{~g}$ for $5 \mathrm{~min}$ at $4^{\circ} \mathrm{C}$. Discard the supernatant and inverse the tubes on an absorbing paper for 2 minutes to remove the maximum of acetone. Then let the remaining acetone evaporate for 2 minutes (you can also pipet the 
remaining acetone if too much is left). Add $300 \mu$ of 4 HES and resuspend the pellet by pipetting (see Note 12).

3.2.3. Hydroxylamine treatment and biotinylation: split the lysate obtained in the previous step by pipetting $120 \mu \mathrm{l}$ in 2 dolphin Eppendorf tubes. Add $480 \mu \mathrm{l}$ of $+\mathrm{HA}$ buffer in one tube (sample with hydroxylamine) and $480 \mu \mathrm{l}$ of $-\mathrm{HA}$ buffer in the second (negative control without hydroxylamine) (See Note 13). Incubate for 1 hour at room temperature (RT) on a wheel.

3.2.4. Protein precipitation and biotin-HPDP removal (see Note 14): add $1200 \mu$ l of ice-cold acetone in each tube, mix the tubes by inversions and incubate for $15 \mathrm{~min}$ at $-20^{\circ} \mathrm{C}$. You see the presence of a white precipitate. Centrifuge at $2500 \mathrm{~g}$ for $5 \mathrm{~min}$ at $4^{\circ} \mathrm{C}$. You obtain a white visible pellet. Remove the supernatant and wash the pellet with $600 \mu \mathrm{l}$ of ice-cold acetone. Centrifuge at $2500 \mathrm{~g}$ for $5 \mathrm{~min}$ at $4^{\circ} \mathrm{C}$. Make sure that you remove all the acetone (by pipetting the remaining acetone and let it dry $2 \mathrm{~min}$ ) and resuspend the pellet in $120 \mu \mathrm{l}$ of 4HES (see Note 12).

\subsection{Avidin capture}

3.3.1. Put $100 \mu$ l of lysate obtained in the previous step in a new dolphin tube. Add $1100 \mu \mathrm{l}$ of dilution buffer to reach a SDS concentration compatible with avidin capture. Centrifuge 1 min at maximum speed to remove all insoluble material. Pipet the supernatant and transfer in a new tube (see Note 15). 
3.3.2. Pipet $90 \mu \mathrm{l}$ of the diluted lysate in a new Eppendorf tube to have a total lysate control before avidin immunoprecipitation and add $30 \mu$ of Laemmli buffer $4 \mathrm{X}$ (without reducing agent). Keep it at $-20^{\circ} \mathrm{C}$.

3.3.3. Add $45 \mu$ l of neutravidin beads in a new dolphin tube for each sample. Add $500 \mu$ of dilution buffer, mix the tubes by inverting and centrifuge at $400 \mathrm{~g}$ for $4 \mathrm{~min}$ at RT (see Note 16). Remove the supernatant and add the remaining $1110 \mu \mathrm{l}$ of diluted lysate to the beads. Incubate 1 hour at RT on a wheel.

3.3.4. Centrifuge at $400 \mathrm{~g}$ for $4 \mathrm{~min}$ at $4^{\circ} \mathrm{C}$ (see Note 17). Remove the supernatant, add $1 \mathrm{ml}$ of washing buffer, mix by inverting the tubes and centrifuge at $400 \mathrm{~g}$ for $4 \mathrm{~min}$ at $4^{\circ} \mathrm{C}$. Repeat this washing step 3 additional times and a last one with dilution buffer.

3.3.5. Release bound proteins by reduction of the protein-biotin disulfide link with $\beta$ mercaptoethanol. Add $50 \mu$ l of Laemmli buffer $2 X$ containing $2 \% \beta$-mercaptoethanol on the beads pellet. Incubate at $95^{\circ} \mathrm{C}$ for $10 \mathrm{~min}$ with frequent agitation, centrifuge at maximum speed for $1 \mathrm{~min}$ and recover the supernatant with gel loading tips (by avoiding the beads).Repeat this step with $30 \mu \mathrm{l}$ Laemmli buffer $2 \mathrm{X}$ and mix with the previously recovered supernatant (see Note 18 and 19).

\subsection{SDS-page and western blotting.}

3.4.1. Load the ABE samples on a $8 \%$ SDS-PAGE. Ideally, split your ABE sample and load half on 2 separate gels: one to detect CD95 and a second one internal S-acylated controls (see Note 20). Load also the lysates recovered before the avidin capture supplemented with $2 \%$ $\beta$-mercaptoethanol to detect total (S-acylated and non S-acylated) CD95.

\subsubsection{Transfer on PVDF membranes.}


3.4.3. Block the membranes for 1 hour at RT with blocking solution.

3.4.4. Incubate the membranes overnight with anti-CD95 (and anti-acylated protein control) antibodies at $4^{\circ} \mathrm{C}$ under agitation. Wash 4 times 10 min with TBS-T $1 \mathrm{X}$. Incubate the membranes for 1 hour with HRP-linked secondary antibodies. Wash 4 times 10 min with TBST 1X. Wash a last time with $\mathrm{dH} 2 \mathrm{O}$ to remove salt and detergent.

3.4.5. Incubate your membranes with ECL and proceed to signal visualisation with your usual detection system (film or camera)(Fig.2).

\section{Notes}

1: $A B E$, as indicated by the name of the technique, cannot discriminate between fatty acids incorporated within the proteins but detect more generally protein S-acylation. Only additional results obtained from metabolic labelling assay allows narrowing to Spalmitoylation. However, we cannot exclude that other fatty acids are also incorporated and other approaches such as tandem mass spectrometry are necessary to profil the exact nature of the lipids attached to S-acylated proteins.

2: First prepare shortly before use $2 \mathrm{M}$ dilution of MMTS in dimethylformamide (DMF) which is then used to prepare the blocking buffer.

3: Prepare a $1 \mathrm{M}$ hydroxylamine solution extemporanely by diluting $3.47 \mathrm{mg}$ hydroxylamine hydrochloride in $50 \mathrm{ml}$ water. Adjust $\mathrm{pH}$ to 7.4 .

4: Prepare a $4 \mathrm{mM}$ stock of biotin-HPDP in DMF. Aliquot and store it at $-20^{\circ} \mathrm{C}$. 
5: Streptavidin-agarose beads can also be used but note that Neutravidin has a higher affinity for biotin.

6: To test the specificity of the detected signal, we generated stable cell lines expressing CD95 WT or CD95 mutated on the palmitoylation site (CD95 C199V) and submitted them to ABE (Fig.2A).

7: The amount of CD95 expressing cells used per point will depend on the cell lines used and has to be adapted accordingly. As examples, $20.10^{6}$ suspension T cells (Jurkat) or $15.10^{6}$ colorectal SW480 cells (it represents a $80 \%$ confluent $140 \mathrm{~mm}$ plate) have been used.

8: This could be a pause point. For suspension cells, remove the supernatant and freeze the cell pellet by quickly throwing the Eppendorf tube in liquid nitrogen. For adherent cells, put the cell plates on ice, remove the medium, and instead of directly lysing, scrape the cells in cold PBS 1X. Centrifuge at $300 \mathrm{~g}$ for $5 \mathrm{~min}$ at $4^{\circ} \mathrm{C}$, remove the supernatant and freeze the sample in liquid nitrogen. Samples can be kept in $-80^{\circ} \mathrm{C}$ for up to one month without any obvious signal loss. Add lysis buffer directly on the frozen pellet when needed.

9: In order to optimize the CD95 proteins isolation we deliberately choose to solubilize Fas from the membranes by SDS. This choice is coherent with the following ABE steps requiring SDS for denaturation of proteins. The presence of an enriched Hepes concentration in our Iysis buffer came from the fact that we also could detect Fas nitrosylation with a similar protocol $(16,17)$.

10: SDS-rich blocking buffer allows a complete denaturation of proteins and accessibility of MMTS to all free thiols. An incomplete blockage would result in a false positive signal for Sacylation proteins. 
11: MMTS has to be totally removed as remaining traces of MMTS might compete with biotin-HPDP to thiol accessibility upon hydroxylamine action and modify the expected results.

12: The pellet can be difficult to solubilize. Do not let it dry too much before adding the 4HES buffer. Let it rehydrate in the 4HES buffer before pipetting. If the resuspension is incomplete, transfer everything in an Eppendorf tube and sonicate for $10 \sec (4 \mathrm{~W})$ on ice. Repeat this step if necessary.

13: Adding this control in the experiment is critical as the hydroxylamine dependence and thus the specificity of the biotin labelling has to be demonstrated by a complete absence of signal (Fig.2A and B).

14: Biotin-HPDP has to be totally removed to avoid competition with biotinylated proteins for neutravidin beads.

15: False positive hits could be easily obtained by the presence of insoluble material in your samples that would be pelleted with the beads upon centrifugation. Therefore a particular attention should be drawn when the cell lysate is recovered.

16: Pipetting the avidin beads might be sometimes delicate. Therefore, we advise before adding the cell lysate to visually verify that you have equivalent amount of beads in each tube after a quick centrifugation step.

17: After the centrifugation step, you can pipet $90 \mu$ of lysate and mix it with $30 \mu \mathrm{l}$ of Laemmli buffer $4 x$. This control allows checking whether your neutravidin immunoprecipitation is efficient and not saturated (enough beads to purify all the biotinylated proteins). 
18: This step allows increasing the yield of recovered S-acylated proteins.

19: This could be a pause point: the samples can be kept at $-80^{\circ} \mathrm{C}$ before loading up to one week.

20: As all S-acylated proteins are recovered in addition to CD95, others candidate proteins for S-acylation or known S-acylated proteins used as controls can be detected by specific immunoblotting. In order to compare the amount of S-acylated CD95 obtained in the different samples or conditions, and because loss of materials could be generated by the multiple steps needed, we recommend using as internal controls well-known S-acylated proteins. We used with high reproducibility the glyceraldehyde 3 phosphate dehydrogenase (GAPDH) or the tyrosine kinase Fyn. Assessing equivalent protein biotinylation by loading the protein lysates obtained before the avidin capture and blotting with streptavidin-HRP could be also used as internal control although we found this control less precise.

\section{References}

1. Linder ME \& Deschenes RJ (2007) Palmitoylation: policing protein stability and traffic. Nat Rev Mol Cell Biol 8(1):74-84.

2. Chamberlain LH \& Shipston MJ (2015) The physiology of protein S-acylation. Physiol Rev 95(2):341-376.

3. Tsutsumi R, Fukata Y, \& Fukata M (2008) Discovery of protein-palmitoylating enzymes. Pflugers Arch 456(6):1199-1206.

4. Greaves J \& Chamberlain LH (2011) DHHC palmitoyl transferases: substrate interactions and (patho)physiology. Trends Biochem Sci 36(5):245-253.

5. Drisdel RC \& Green WN (2004) Labeling and quantifying sites of protein palmitoylation. Biotechniques 36(2):276-285.

6. Martin BR, Wang C, Adibekian A, Tully SE, \& Cravatt BF (2012) Global profiling of dynamic protein palmitoylation. Nat Methods 9(1):84-89.

7. Wan J, Roth AF, Bailey AO, \& Davis NG (2007) Palmitoylated proteins: purification and identification. Nat Protoc 2(7):1573-1584.

8. Chakrabandhu K, et al. (2007) Palmitoylation is required for efficient Fas cell death signaling. EMBO J 26(1):209-220. 
9. Feig C, Tchikov V, Schütze S, \& Peter ME (2007) Palmitoylation of CD95 facilitates formation of SDS-stable receptor aggregates that initiate apoptosis signaling. EMBO J 26(1):221-231.

10. Guardiola-Serrano F, et al. (2010) Palmitoylation of human FasL modulates its cell deathinducing function. Cell Death Dis 1:e88.

11. Rossin A, Derouet M, Abdel-Sater F, \& Hueber AO (2009) Palmitoylation of the TRAIL receptor DR4 confers an efficient TRAIL-induced cell death signalling. Biochem J 419(1):185192, $182 \mathrm{p}$ following 192.

12. Utsumi T, et al. (2001) Transmembrane TNF (pro-TNF) is palmitoylated. FEBS Lett 500(1-2):16.

13. Berg V, et al. (2015) miRs-138 and -424 control palmitoylation-dependent CD95-mediated cell death by targeting acyl protein thioesterases 1 and 2 in CLL. Blood 125(19):2948-2957.

14. Peter ME, et al. (2007) The CD95 receptor: apoptosis revisited. Cell 129(3):447-450.

15. Rossin A, et al. (2015) Fas palmitoylation by the palmitoyl acyltransferase DHHC7 regulates Fas stability. Cell Death Differ 22(4):643-653.

16. Leon-Bollotte L, et al. (2011) S-nitrosylation of the death receptor fas promotes fas ligandmediated apoptosis in cancer cells. Gastroenterology 140(7):2009-2018, 2018.e2001-2004.

17. Jaffrey SR \& Snyder SH (2001) The biotin switch method for the detection of S-nitrosylated proteins. SCi STKE 2001(86):pl1. 


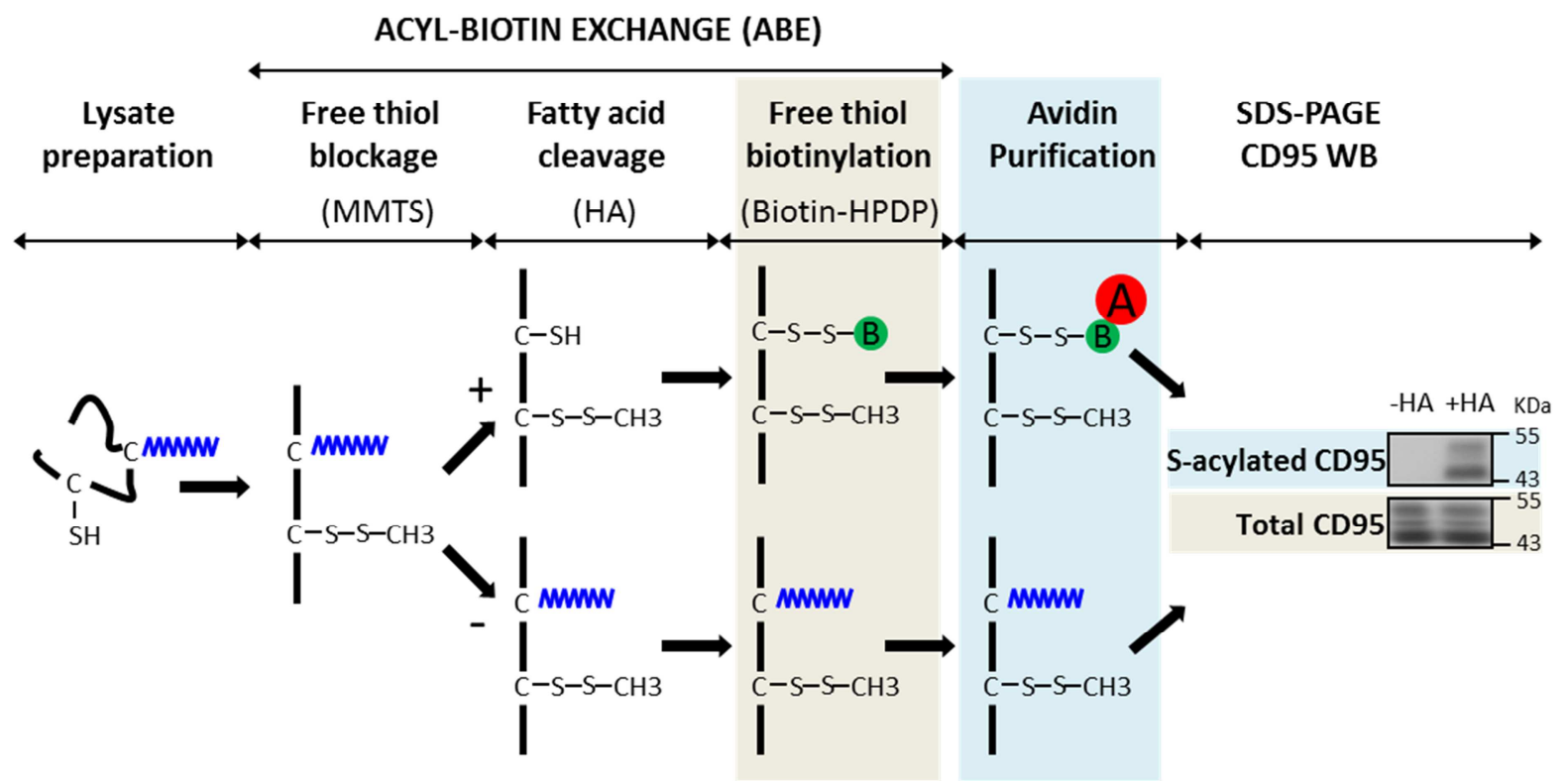

Fig. 1. Schematic representation of $A B E$ technique. MMTS is for methylmethane thiosulfonate, HA for hydroxylamine, biotin-HPDP for N-[6-(biotinamido)hexyl]-3'(2'-pyridyldithio)propionamide, B for biotin, A for Avidin and WB for western blot. 
A.
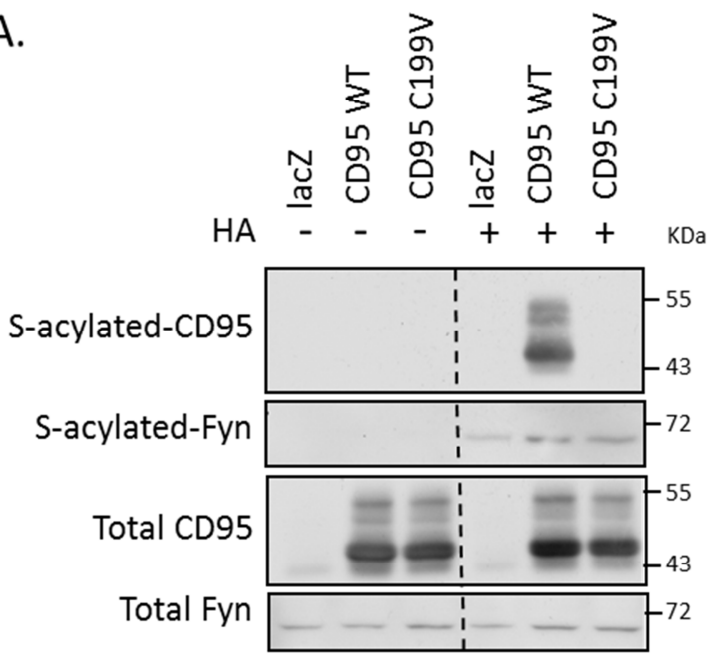

B.

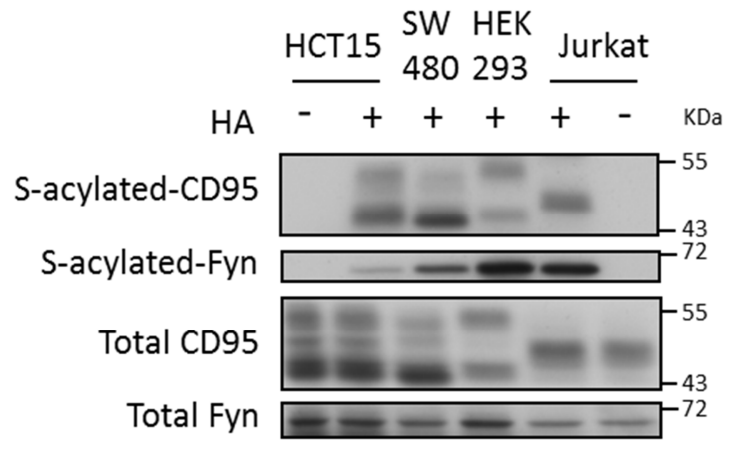

Fig.2. CD95 is S-acylated on cysteine 199. A: SW480 cells stably expressing lacZ, CD95 WT or $\mathrm{CD} 95 \mathrm{C} 199 \mathrm{~V}$ were subjected to $\mathrm{ABE}$ as described in the protocol. Half of the samples were exposed to hydroxylamine $(+\mathrm{HA})$ and half were not $(-\mathrm{HA})$. S-acylated and total CD95 (lysate recovered before avidin purification) were detected with B10 anti-Fas antibody and Fyn was used as internal S-acylated control .B: Suspension (Jurkat) and adherent (HCT15, SW480 and HEK293) cells were subjected to ABE and the endogenous level of S-acylated CD95 is shown here. S-acylated and total CD95 (lysate recovered before avidin purification) were detected with EPR520 anti-Fas antibody and Fyn was used as internal S-acylated control. 